\title{
MENGGALI POTENSI CREATIVRENEURSHIP ERA RI 4.0 MELALUI \\ PEMBELAJARAN SEJARAH KREATIF
}

\author{
Nana Supriatna \\ Email:nanasup@upi.edu \\ (Guru Besar Pendidikan Sejarah UPI)
}

\begin{abstract}
Abstrak
Tulisan berbasis pemikiran dan penelitian sesuai dengan judulnya bertujuan untuk menggali creativpreneurship peserta didik melalui pembelajaran Sejarah. Tulisan ini merujuk pada proses bimbingan mahasiswa program pengalaman lapangan (PPL) di salah satu Sekolah Menegah Atas (SMA) Kabupaten Bandung Barat. Melalui dialog dengan mahasiswa dan guru pamong PPL disepakati memilih materi pelajaran dari kelas X mengenai topik Zaman Kerajaan-kerajaan Islam di Indonesia sesuai dengan Kurikulum 2013. Topik tersebut juga dihubungkan secara kreatif dengan sejarah lokal peserta didik termasuk kehidupan graris zaman sistem Tanam Paksa abad ke-19 dan kehidupan kontemporer abad ini. Tidak ada rumusan Kompetensi Inti (KI) mengenai creativreneurship dalam rumusan kurikulum tersebut. Tidak juga ada rumusan Kompetensi Dasar (KD) serta deskripsi materi pelajaran terkait dengan konsep itu. Namun demikian, semangat mahasiswa PPL untuk mengangkat kecakapan tersebut tidak bisa dibendung dan saya sebagai pembimbing harus memfasilitasinya. Hasrat untuk mengangkat isu berbeda dari arus besar pedagogi sejarah dan mungkin out of the box merupakan salah satu pikiran kreatif. Mahasiswa PPL yang juga berasal dari daerah dimana sekolah berada - penghasil sayur-sayuran memiliki cara pandang yang baik mengenai masalah-masalah yang dihadapi di daerahnya. Dia memahami betapa pentingnya membekali peserta didik tentang entrepreneurship di sekolahnya yang berlokasi di daerah penghasil tanaman sayuran. Dia juga memahami bahwa - walaupun sebagian peserta didik di sana berlatarbelakang orang tua petani atau berhubungan secara ekologis dengan kondisi agraris - sangat sedikit yang bercita-cita menjadi petani. Guru pamong dan saya membiarkan mahasiswa tersebut mengembangkan pedagogi dengan caranya sendiri. Hasilnya ternyata menggambarkan apa yang disebut sebagai pedagogi kreatif yang menghasilkan proses pembelajaran yang kreatif pula serta peserta didik yang juga ditantang untuk kreatif dalam melihat potensi di daerahnya. Uraian di bawah ini mendeskripsikan creativreneurship sebagai kompetensi unggulan di era Revolusi Industri 4.0 (IR 4.) dalam bidang ekonomi yang digali dalam perkembangan historis. Diuraikan pula potensi creativreneurship peserta didik melalui pedagogi kreatif pembelajaran Sejarah.
\end{abstract}

\section{A. Mendekonstruksi Kurikulum dengan Menambah Isu creativpreneurship}

Mendekonstruksi - meminjam istilah Munslow (2011) yang diterjemahkan menjadi mombongkar - benar-benar dilakukan oleh mahasiwa PPL yang kami bimbing. Dia mengatakan bahwa Kurikulum Tahun 2013 termasuk dalam mapel Sejarah perlu dikembangkan sesuai dengan persoalan di derahnya. Sekolah juga tidak memiliki analisis kurikulum yang seharusnya berisi pengayaan sesuai dengan situasi dan kondisi lingkungan sekolah. Sekolah hanya 
menggunakan silabus yang sudah dibuat oleh pengembang Kurikulum di tingkat pusat, Jakarta. Isu-isu mengenai dunia agraris yang dihadapi peserta didik tidak terwadahi dalam kurikulum terebut. Oleh karena itu, dia menginginkan agar kurikulum menjadi tempat bagi guru berimprovisasi dan mengemas pembelajaran yang relevan dengan persoalan di mana peserta didik berada. Saat belajar Sejarah di SMA dulu, dia hanya dibekali gurunya mengenai fakta-fakta Sejarah. Bila dia bisa menjawab soal-soal pilihan ganda maka dia dinyatakan lulus. Nilai tinggi yang dia dapat dirasakan tidak bermakna bagi kehidupannya. Pelajaran sejarah berakhir sampai kurun waktu materi pelajaran disampaikan oleh gurunya. Tidak ada upaya guru untuk menghubungkan konsep atau masalah yang ditemukan dalam sejarah dengan kehidupan nyata dirinya pada era dia hidup masa kini. Padahal, konsep-konsep dalam sejarah yang bisa dipinjam dari ilmu-ilmu sosial seperti kewiraswastaan, etos kerja, kearifan lokal, perjuangan, kemerdekaan, kebudayaan, peradaban dan lain-lain untuk dikembangkan sebagai jembatan penghubung antara masa lalu dengan masa kini (Supriatna, 2007).

Pada saat berdialog dengan saya dan dia mengusulkan gagasan berbeda tentang pentingnya memasukkan creativpreneurship saya meresponnya secara positif. Saya senang, dari sekian mahasiwa yang saya bimbing di kelas tidak ada mahasiswa yang mengusulkan "ide-ide berontak" seperti dia. Bagaimana bisa, konsep dari disiplin ilmu ekonomi atau di luar Sejarah bisa dikembangkan dalam pembelajaran Sejarah? Pertanyaan tersebut tidak akan dengan mudah dijawab oleh mahasiswa yang suka berpikir convergent, meminjam istilah dari Guilford, (1950) dalam Runco and Jaeger, 2012) yaitu berpikir linier atau normatif dan tidak suka dengan pikiran berbeda. Sebagian besar mahasiswa PPL hanya menurut pada dosennya, mengikuti saran-saran guru pamong dan memilih menggunakan format silabus dan rencana program pembelajaran (RPP) yang sudah tersedia.

Alasan mengusulkan konsep creativpreneurship karena dia merasa kecakapan itu penting dimiliki oleh peserta didik, termasuk kompetensi dalam berkreasi memanfaatkan potensi lahan subur dan iklim yang baik untuk pertanian sayuran. Dia merasa terpanggil untuk menginspirasi pesert didik di sana untuk mencintai daerahnya. Sangat sedikit, kalau disebut tidak ada sama sekali, peserta didik yang ingin menjadi petani. Dalam pandangannya, petani pada masa kini tidak harus seperti petani penggarap sebagaimana orangtua peserta didik kini. Petani pada masa zaman now adalah seperti salah seorang petani muda yang berasal dari daerah tersebut yang kini bertani dengan cara kreatif dengan memanfaatkan teknologi komunikasi dan informasi dalam 
mengelola pertanian. Petani tersebut menjadi seorang creativpreneur dalam memanfaatkan peluang, berkreasi dalam mengemas hasil pertanian, menjualnya secara online dan berjejaring untuk menjangkau konsumen yang dituju. Mahasiswa yang saya bimbing ini mengusulkan agar petani tersebut diundang ke dalam kelas dan menjadi narasumber dalam pembelajaran Sejarah. Usulan terebut juga saya turuti apalagi setelah membaca buku Morris (2009) tentang pentingnya menampilkan first person historical presentation yang dihubungkan ke dalam kehidupan peserta didik

Mahasiswa saya juga belajar dari materi perkuliahan bahwa isu pertanian adalah isu klasik. Sejak dulu petani selalu menjadi korban dari hegemoni kekuasaan. Dia memahami dengan baik bahwa kehidupan petani dari zaman ke zaman tidak lebih baik dalam arti meningkatkan status sosialnya. Mereka selalu menjadi objek dari hegemoni kelompok yang berkuasa, baik penguasa lokal maupun kolonial Belanda (Kartodirdjo, 1995). Misalnya, kebijakan kolonial mengenai Tanam Paksa (cultuur stelsel) tahun 1830-1870 hanya menguntungkan pamong praja dan pemerintah kolonial Belanda. Memasuki zaman merdeka pun sebagian petani hanya menjadi alat produksi untuk peningkatan pangan bagi kehidupan seluruh bangsa.

Belajar dengan cara mengunduh sumber-sumber online mengenai bagaimana negaranegara industri mengembangkan pertanianya, dia terinspirasi untuk membuka wawasan peserta didik di daerah penghasil sayur-sayuran itu untuk tetap menggarap potensi besar ini. Kisah sukses Thailand sebagai negara agraris dan bisa mengangkat para petaninya juga menginspirasinya. Dia ingin menanamkan berpikir kesejarahan sebagai masyarakat agraris yang mencintai daerahnya dengan tindakan kreatif mengembangkan sektor tersebut dan dengan memanfaatkan peluang-peluang di era digital dewasa ini. Dia juga ingin memanfaatkan gawai peserta didik untuk menunjang pembelajaran sejarah sekaligus membimbing mereka literasi digital agar mereka tidak hanya menjadi masyarakat konsumtif yang berorientasi pada kehidupan perkotaan sebagai masyarakat konsumen (Supriatna, 2018)

Ketika kami menyetujui usulan tersebut masalah baru timbul dan dengan dialog bisa diatasi. Dalam dokumen Kurikulum 2013 dan yang sudah direvisi tahun 2016 pada pelajaran Sejarah SMA tidak terdapat kompetensi yang ingin dikembangkannya. Tidak ada rumusan KI atau KD terkait dengan etos kerja sebagai ciri entrepreneur atau pengusaha kreatif termasuk dengan menghubungkannya dengan materi Sejarah. Dalam pandangan saya, seharusnya pada 
meteri mengenai Masuk dan Berkembangnya Islam di Indonesia dimasukkan ke dalam dokumen kurikulum mengenai dunia perdagangan. Salah satu teori mengenai masuk dan berkembangnya Islam ke Indonenia adalah teori tentang peranan pedagang dalam memperkenalkan ajaran Islam di kawasan pesisir pantai antara Zasirah Arab, Persia, semenanjung India dan Kepulauan Nusantara. Teori tersebut bisa diperkuat dengan kajian atau pengayaan materi mengenai etos kerja pada pedagang. Nilai-nilai kerja keras sebagai keunggulan para pedagang Islam pada zamannya dalam menghadapi tantangan alam dan keberanian mengambil risiko merupakan ciri yang juga melekat pada orang-orang yang memiliki jiwa kewiraswastaan. Demikian juga, kemampuan berkomunikasi dan berjejaring dengan pedagang lainnya di berbagai tempat dan pemahaman mengenai aspek geografis mitra dagang juga merupakan keunggulan yang memiliki relevansi dengan nilai-nilai tersebut. Kemampuan memilih, mengolah dan menjual barang dagangan juga menggambarkan aspek kreatifitas. Karakter sebagai pedangan yang memanfaatkan laut sebagai jalur perdagangan menunjukkan ciri masyarakat bahari yang juga seharusnya masuk ke dalam dokumen kurikulum. Unsur-unsur kreatifitas yang seharusnya nampak pada materi kontekstual itu tidak ada dalam dokumen Kurikulum tahun 2013.

Oleh karena itu, kami menyepakati untuk memasukkan isu-isu terebut dan Mahasiswa PPL sangat bergembiara. Ide-ide kreatifnya dalam "membongkar kurikulum" yang ada dan membangunnya kembali dengan pengayaan materi kontektual difasilitsi oleh pembimbingnya. Ini seperti kurikulum hidup atau living curriculum yang menghubungkan antara dokumen kurikulum dengan kebutuhan peserta didik. Peserta di daerah ini membutuhkan motivasi melalui materi pembelajaran termasuk untuk mencari inspirasi bagaimana menjadi pelaku Sejarah di di daerahnya (Supriatna, 2007) sebagai petani kreatif atau bisa menggali potensinya untuk dikembangkan sebagai sumber kehidupan. Mahasiswa PPL juga mengusulkan untuk memperkaya kurikulum dengan kisah-kisah pedagang di berbagai daerah melalui ceritera rakyat atau folkrore termasuk penggunaan biografi. Biografi pengusaha Chairul Tanjung berjudul $S i$ Anak Singkong yang sudah dia baca juga ingin dimasukkannnya ke dalam materi pelajaran. Dari kesepakatan tersebut kami meminta mahasiswa menyusun RPP dengan memasukkan indikatorindikator tentang kompetensi yang dimaksud.

Ini merupakan awal dari bagaimana pedagogi kreatif dirancang sebelum dikembangkan dalam proses pembelajaran. Bunyi kompetensi dasar dalam Kurikulum Tahun 2013 yang dimulai dengan kata kerja memahami, menyajikan hasil, menerapkan konsep, menganalisis dan 
menyajikan informasi tidak hanya diteruskan atau diikuti dengan isi materi yang sudah dirumuskan dalam dokumen kurikulum resmi. Kata kerja tersebut dikuti dengan konsep creativprneurship yang ingin dikembangkannya. Misalnya, kata kerja menyajikan hasil bacaan mengenai ciri-ciri karakter pedagang masa kerajaan Islam yang bisa diteladani untuk masa kini ditambahkan ke dalam rumusan kompetensi. Demikian juga kata kerja menganalisis tidak hanya terkait dengan teori masuk dan berkembangnya Islam di Indonesia melainkan dengan rumusan menganalisis etos kerja masyarakat bahari yang berdagang pada masa kerajaan-kerajaan Islam. Rumusuan indikator kompetensi peserta didik dalam memahami arti creativpreneurship, memahami fakta-fakta sejarah terkait dengan aspek itu, menyadari pentingnya berwirausaha secara kreatif dan menyadari pentingnya hal itu dalam menjalani kehidupannya juga dirumuskan. Tidak kalah pentingnya, terdapat rumusan indikator: peserta didik mendeskripsikan cita-citanya mengenai profesi petani seperti apa yang diinginkan di masa depan. Demikian juga, dalam RPP yang memasukkan kisah sukses Si Anak Singkong dilengkapi dengan indikator mengambil pelajaran dari kreatifitas Chairul Tanjung dalam melihat peluang-peluang usaha.

Terdapat pikiran-pikiran kreatif mahasiswa dalam memasukkan peserta didik sebagai pelaku sejarah pada zamannya. Caranya dengan menambahkan kata kamu ke dalam materi dan kegiatan pembelajaran. Misalnya dalam rencana kegiatan belajar mengajar terdapat kegiatan tanya jawab dan dia merumuskan pertanyaan menarik. Pertanyaan tersebut berbunyi, jika kamu sebagai pedagang pada masa Kesultanan Islam Banten apa yang akan kamu lakukan agar perdagangan kamu terus meningkat dan mendatangkan keuntungan yang banyak? Dalam hal ini pedagogy kreatif merupakan rancangan pembelajaran kreatif guru yang bisa memfasilitasi terjadinya proses kreatif sehingga menghasilkan peserta didik yang juga kreatif. Ini seperti mengingatkan pada definisi pedagogy kreatif dari Selkrig dan Keamy (2017) bahwa pedagogy kreatif itu meliputi tiga unsur yaitu creative teaching, teaching for creativity dan creative learning. Rumusan RPP di atas menggambarkan semangat dalam merancang untuk menghasilkan creative pedagogy sehingga bermuara pada proses belajar mengajar yang kreatif yang diawali dengan RPP kreatif sehingga memfasilitasi peserta didik yang memiliki kompetensi creativpreneurship. Dokumen kurikulum yang belum mengakomodasi pentingnya peserta didik mengenal lebih dalam daerahnya dikembangkan lebih lanjut sehingga menghasilkan rencana pembelajaran yang lebih kontekstual. 
Uraian berikut akan mendeskripsikan bagaimana pedagogi kreatif memfasilitasi kegiatan belajar kreatif sehingga menghasilkan peserta didik yang memiliki kesadaran sejarah dalam melihat peluang-peluang yang ada di daerah mereka. Sebelum lanjut pada subjudul di atas terlebih dahulu diuraikan definisi creativprneurship dengan merujuk pada hasil-hasil riset dan bagaimana pembelajaran Sejarah mengemasnya menjadi pembelajaran baru atau new learning (Harris and de Bruin, 2017).

\section{B. Mewadahi Creativepreneurship Era IR 4.0 dalam Pembelajaran Sejarah}

Mewadahi creativpreneurship dilakukan dengan memasukkannya ke dalam kurikulum pembelajaran termasuk Sejarah. Secara historis, istilah itu lahir sebagai fenomena historis dan terus berkembang hingga kini. Perubahan sosial politik seperti peperangan yang menghancurkan tatanan social ekonomi direspons dengan cara berbeda atau tidak biasa sehingga kehidupan social-ekpnomi bisa pulih kembali. Para ekonom era Perang Dunia Pertama (1914-1919) dan Perang Dunia II (1939-1945) menawarkan alternative pemecahan masalah social-ekonomi akibat dampak buruk peperangan. Ini tidak berbeda dengan berkembangnya teknologi informasi di Era IR 4.0 abad ini juga melahirkan tantangan baru bagaimana menciptakan ekonomi kreatif guna menghasilkan cara-cara baru dalam memanfaatkan perubahan tersebut. Ekonom berkebangsan Austria yang mengajar di Harvard University, menjadi pelopor lahirnya istilah creative economy dalam menawarkan alternatif pemecahan persoalan sejarah manusia yang diakibatkan peperangan. Pada tahun 1934 dia melahirkan istilah creativpreneurship sebagai sebuah respon terhadap ekonomi dunia yang mengalami kehancuran akibat konflik antarbangsa. New economy ditawarkannya dengan istilah Economic Theory of Creative Destruction dengan memperkuat konsep kreativitas ke dalam ekonomi, dengan cara breaking up established systems dan membuka cara-cara baru dalam mengatasi persoalan ekonomi. Konsep creativpreneurship yang merupakan paduan dua konsep creative dan enterpreneurship dipopulerkannya pada tahun 1947.

Konsep tersebut kemudian dipopulerkan oleh Bilton (2010). Dia merespon efek disruptive dalam bidang usaha melalui creative destruction untuk memperbaharui established businesses dan melakukan rekonstruksi kembali. Teori ini merujuk pada neoclassical theory yang disebut The Profit Maximizer (Endogenous Growth Theory) (Romer, 2006) yang menitikberatkan pada determinan knowledge-based firm dengan menggerakan innovation sebagai peran sentral dalam entrepreneurship (Friis et al, 2006). Konsentrasi creative entrepreneur berbeda antara typical 
business atau social entrepreneur dalam mengkreasi dan mengeksploitasi modal intelektual (intellectual capital) atau disebut juga sebagai investor talenta (Caves, 2000; 2003).

Salah satu ciri dari creativpreneurship adalah inovasi. Konsep tersebut dikenal dalam sejarah dan menandai kesinambungan dan perubahan masyarakat bangsa. Perubahan di dunia disebabkan oleh inovasi dalam berbagai aspek kehidupan. Ditemukannnya alat-alat baru berpengaruh terhadap kehidupan baru dan terus mengalami perubahan hingga melahirkan invoasi-inovasi lainnya. Konsep inovasi bisa dijadikan sebagai jembatan penghubung antara zaman tertentu dengan masa yang dialami peserta didik. Oleh karena itu, konsep inovasi masuk ke dalam kurikulum pembelajaran Sejarah. Inovasi dalam bidang ekonomi sebagai salah satu wujud creativpreneurship Schumpeter ditandai dengan adanya prosedur atau cara baru dalam kegiatan ekonomi yang meliputi gagasan kebaruan dalam produk, metode produksi, pasar dan organisasi (Oscarius, 2016). Creative entrepreneurship sebagai Creativity-based entrepreneurship merupakan kelanjutan dari teori Wallas (1926) (sebagaimana dikutip SadlerSmith (2016) tentang Model of Creative Thinking dan creativity-based Model of Entrepreneurial Opportunity Recognition (Lumpkin et. al; 1996; 2004). Mengacu pada teori tersebut terdapat lima tahapan formasi peluang pada creativity-based entrepreneurship yaitu: preparation (unconscious awareness), incubation of ideas, insight (the moment of discovery), evaluation and elaboration (Fillis, I., 2010). Creativity memiliki unsur gagasan atau idea baru (novelty), kegunaan, dan ketepatan atu kecocokan (fit) dalam aplikasinya (Duxbury, 2012). Secara state of art, creativity memiliki empat unsur $\mathrm{P}$, yaitu personality, product, process, dan press (Kolnhofer-Derecskei, 2016). Pada dunia usaha, creativity menjadi unsur penting entrepreneurship dalam mengidentifikasi masalah, menjalankan kepemimpinan, dan mengembangkan produk (Fillis \& Rentschler, 2011; Schmidt et al, 2013). Di era ekonomi competitiveness dan cooperation yang semakin kompleks ini, creativity merupakan the soul of entrepreneurship (Kuratko \& Morris, 1995; 2002; Dayan \& Benedito, 2009; Kačerauskas, 2015).

Ciri-ciri creativpreneurship dalam pengembangan pembelajaran Sejarah disederhanakan sehingga bisa dipahami dengan baik oleh peserta didik. Pengalaman berbagai kelompok masyarakat pada ruang dan waktu perjalanan sejarah dalam mengatasi berbagai masalah kehidupan dapat disebut sebagai tindakan kreatif dan inovatif. Pada masyarakat praaksara, misalnya, api bisa diciptakan dengan menggesek-gesekan dua benda sehingga menghasilkan panas yang kemudian menjadi api ketika benda lembek seperti daun kering didekatkan dengan 
benda panas tersebut. Beberapa tindakan inovatif kemudian muncul seperti bagaimana api digunakan untuk memanaskan daging binatang buruan, membakar lahan untuk memperluas wilayah permukiman atau menjaga lingkungan dari ancaman binatang buas. Tindakan kreatif dan inovatif lainnya nampak pada penggunaan batu sebagai alat menopang kehidupan. Peralatan batu kemudian ditinggalkan ketika logam ditemukan dan dikembangkan menjadi alat-alat yang lebih kuat, tajam dan tahan lama. Api yang bisa meleburkan benda-benda termasuk logam telah menghasilkan berbagai alat yang pada zamannya sebagai alat-alat baru yang berbeda dengan alat-alat kurun waktu sebelumnya. Peralatan pertanian, senjata, benda seni dan lain-lain tercipta karena masyarakat menggunakan akal pikirnya secara kreatif sehingga menghasilkan inovasi. Proses perjalanan masyarakat dalam sejarah seperti itu layak dikembangkan dalam pembelajaran sejarah untuk membekali peserta didik berpikir dan bertindak secara kreatif.

Peradaban dunia berkembang karena masyarakat pendukungnya menggunakan akal pikirnya untuk menghasilkan gagasaan dan karya-karya kreatif. Pikiran dan karya mereka mempengaruhi masyarakat dunia. Setiap temuan alat-alat baru yang berguna bagi kehidupan mereka diikuti dengan temuan-temuan inovatif yang lebih baik dan berguna pada zamannya. Alat-alat lama yang tidak berguna ditinggalkan. Misalnya, dalam kurun waktu 1750-1850 di Inggeris merupakan masa berkembangnya karya-karya kreatif yang memperkuat lahirnya Revolusi Industri. Alat pintal dan tenun untuk menghasilkan kain segera ditinggalkan ketika alatalat baru berupa mesin diciptakan. Karya-karya kreatif berupa mesin pintal dan tenun menggantikan alat-alat sejenis yang memerlukan tenaga kerja banyak dan kapasitas produksi yang rendah. John Kay pada tahun 1733 berhasil menciptakan alat tenun yang lebih menghasilkan kain lebih banyak dan dengan jumlah tenaga kerja sedikit. Pada tahun 1764 James Hargreaver menciptakan mesin pintal wol yang lebih cepat bekerja sehingga jumlah produksi meningkat. Mesin-mesin mereka disempurnakan lagi melalui karya inovatif penemu lainnya seperti Cotton Gin karya Eli Witney tahun 1794. Melalui temuan terakhi industry tekstil berkembang dengan baik dan kemudian melahirkan karya kreatif menjadi bidang ussaha besar. Creativpreneurship pada waktu itu memang belum dikenal. Akan tetapi, ciri-cirinya yang nampak dalam berpikir dan menghasilkan karya yang orisinil, mengembangkan karya berbeda dengan sebelumnya dan bermanfaat atau aplikatif pada zamannya sudah ditunjukkan oleh para penemu era tersebut. Misalnya, persoalan sulitnya komunikasi antara wilayah dibantu oleh temuan kreatif mesin telegraf pada awal tahun 1800an. Melalui temuan tersebut komunikasi 
antara wilayah dan kawasan dunia bisa lebih cepat termasuk untuk menginformasikan produkproduk industri ke daerah pemasaran. Tentu saja temuan mesin uap oleh James Watt tahun 1775 yang menandai percepatan alat angkutan darat dan laut dipercepat kembali dengan temuan lokomotif oleh Richard Travetik dan George Stevenson tahun 1804 (Buckler, 1988). Karyakarya kreatif dan inovatif tersebut dan temuan-temuan lainnya telah mempercepat revolusi industry dan mengubah masyarakat dunia termasuk Indonesia.

Berbagai karya kreatif dan inovatif telah mempengaruhi lahirnya revolusi industry kedua, ketiga dan keempat (disingkat RI 1.0, RI 2.0, RI 3.0 dan RI 4.0). Jika RI 1.0 ditandai dengan karya-karya kreatif dan inovatif pada aspek mesin uap untuk menggerakkan alat tenun dan pintal industri tekstil maka pada RI 02 yang berlangsung antara 1870-1914 ditandai dengan karya inovatif yang jauh lebih maju. Di periode ini temuan listrik telah mempercepat industri dengan produksi masal. Selain listrik, karya inovatif periode ini antara lain telefon, bola lampu dan fonograf. Sedangkan RI 3.0 yang dimulai tahun 1980-an ditandai dengan pengembangan komputer, internet, teknologi informasi dan kemunikasi yang terus berkembang hingga sekarang. Bersamaan dengan itu, khususnya sejak awal abad ke-21, dunia memasuki RI 4.0. Dalam revolusi terakhir ini, berbagai karya kreatif dan inovatif diciptakan dan semua itu telah mempercepat proses revolusi. Dikembangkannya mesin cerdas otomatis seperti robot telah membantu pekerjaan manusia. Demikian juga dengan kecerdasan buatan, nanoteknologi, bioteknologi, Internet of Things dan lain-lain merupakan tantangan tidak hanya untuk menghasilkan karya-karya kreatif melainkan juga cara meresponsnya secara kreatif.

Keuntungan manusia dari RI 4.0 adalah otomatisasi dan digitalisasi dalam berbagai aspek kehidupan manusia. Sekali pun mesin telah membantu manusia dalam mempermudah menjalankan kehidupannya akan tetapi ada aspek yang tidak bisa digantikannya. Aspek tersebut adalah otak manusia yang bisa melahirkan pikiran-pikiran baru atau karya-karya yang baru yang kreatif. Dengan demikian, kretifits tidak bisa digantikan oleh mesin. Di era cyber physical system kegiatan ekonomi pun dilakukan dengan cara baru yang nampak pada istilah new economy. Kegiatan ekonomi yang sifatnya cultural berubah menjadi ekonomi kreatif (Garnham, 2006). Di era inilah kompetensi creativpreneurship menjadi kompetensi yang harus dimiliki oleh generasi yang hidup di era ini. Diperlukan pedagogi yang bisa memfasilitasi peserta idik dalam kemampuan untuk menghasilkan peluang-peluang baru dalam usaha baik dalam bentuk produk yang baru, ataupun cara pengelolaan yang baru sehingga menghasilkan nilai guna bagi 
masyarakat. Dalam pembelajran Sejarah, kemampuan melahirkan interpretasi baru, menghubungkan masa lalu dengan masa kini, mengambil pelajaran dari pengalaman kreatif masa lalu dan memikirkan tindakan kreatif untuk memecahkan masa kinimreupakan bagian dari berpikir kreatif. Menghubungkan pengalaman historis dari zaman dulu dan yang dialami masyarakt lain diluardaerah mereka dan dihubungkannya dengand aerah merupa meerupakan kemampuan berpikir kreatif. Bila hal itu dihubungkan dengan dunia usaha maka unsur creativepreneurship juga maemiliki relevansi dengan pembelajaran Sejarah. Melalui pembelajran Seajrah, peserta didik harus difasilitasi dengan kemampuan dalam melahirkan gagasan baru dari peluang usaha masyarakat agraris ataupun bahari di sekitar mereka.

\section{Mendekatkan Creativreneurship dengan Sejarah Lokal Peserta Didik}

Pembelajaran Sejarah yang kreatif adalah pembelajaran yang mendekatkan peserta didik dengan peristiwa historis. Kejadian-kejadian historis dis ekitar peserta didik, termasuk sejarah lokal, merupakan materi pelajran yang bisa menginspirasi termasuk dalam mengembangkan kreatifitas. Ini tidak berarti peristiwa yang jauh dari daerah peserta didik tidak bisa didekatkan dengan mereka. Berbagai peristiwa Sejarah mengeni tindakan kreatif berupa karya inivasi teknologi pada masa RI 1.0 dapat didekatkan dengan menggunakan konsep kreatifitas itu sendiri. Sejarah RI 1.0 dapat digunakan untuk menginspirasi peserta didik bahwa berbagai karya inovatif telah mengubah dunia. Mereka dapat diajak beranalogi mengenai diri mereka pun bisa melakukan tindakan historis dengan menghasilkan karya kreatif yang bisa mengubah dunia di sekitar mereka. Peristiwa RI 4.0 pun yang jauh dari peserta didik bisa didekatkan dengan peserta didik. RI 4.0 merupakan tantangan dan bila peserta didik tidak dibekali dengan kompetensi dalam meresponsnya maka dampak buruk bisa melanda mereka. Kompetensi kreatif menjadi sangat penting untuk dikembangkan agar mereka mampu menghadapi berbagai tantangan era ini. Dalam bidang ekonomi misalnya, peserta didik dihadapkan pada kondisi ekonomi baru yang mengharuskannya memiliki keterampilan masa depan yang tidak bersifat mekanistis. Siswa didorong untuk memiliki keterampilan-keterampilan inovatif yang berguna bagi kehidupannya. Karya-karya inovatif yang diwariskan dari sejarah lokal peserta didik bisa menjadi materi yang menarik. Misalnya, tradisi mengolah rempah yang menjadi jamu, obat-obatan dan untuk perawatan tubuh (Supriatna, 2018) merupakan materi yang bisa memperkaya pembelajaran. 
Melalui catatan sejarah mengenai hal itu peserta didik ditantang memikirkan dan menghasilkan karya kreatif untuk memanfaatkan dan mengembangkannya.

Untuk mengembangkan creativepreneurship dibutuhkan pedagogi yang kreatif pula. Pedagogi konvensional yang selama ini digunakan guru bisa diperbarui dengan menambahkan unsur-unsur baru yang relevan dengan tantangan zaman. Pemanfaatan teknologi informasi tidak selalu relevan untuk menginspirasi peserta didik mengenai kreatifitas. Sebaliknya metode tradisional seperti ceramah dan tanya jawab yang dikemas dengan cara baru bisa menginspirasi peserta didik berpikir kreatif.

Froebel - dalam Ornstein, Levine \& Gutek, (2011) - menawarkan cara lama untuk menumbuhkan nilai-nilai dan sikap positif dalam menghadapi tantangan. Pembelajaran Sejarah yang tradisional pun bisa menjadi cara yang menginspirasi untuk menghasilkan gagasan kreatif. Dia menawarkan pemanfaatan lagu daerah, dongeng masyarakat lokal, cerita, permainan tradisional, seni dan kerajinan sebagai metode tradisional yang menginspirasi dan menumbuhkan imajinasi peserta didik. Morris (2009) menambahkan bahwa pembelajaran Sejarah dapat membekali peserta didik keterampilan-keterampilan mengambil peran, menginterpretasikan karakter tokoh sejarah dan belajar membuat keputusan yang didasarkan pada lingkungan tempat mereka tinggal. Mereka bahkan dapat menilai sendiri dampak atas tindakan mereka. Sejarah dapat memberikan pengalaman yang berharga dan menyenangkan bagi peserta didik mengantarkan mereka pada penemuan nilai-nilai dan keterampilan-keterampilan sosial yang tergambar melalui peristiwa sejarah. Pada akhirnya siswa dapat menarik kesimpulan dan menjadikan sejarah sebagai penemuan reflektif yang dapat diaplikasikan ke dalam kehidupannya. Isi materi pelajaran Sejarah dapat disederhanakan, didekatkan dengan peristiwa kehidupan peserta didik. Isi materi pelajaran yang sifatnya problematis dan kontroversial menjadi bahan menarik untuk didiskusikan. Melalui cara itu, peserta didik dapat berperan untuk menawarkan gagasan atau berpikir kreatif dalam menemukan peluang-peluang inovasi baru dalam memecahkan masalah (Avishag, R.\& Sam, W., 2008; Barry K. B., 2008). Dalam pandangan Webb, Meckstroth, \& Tolan, 1982, hlm. 177; Brewer, 2006) Sejarah lokal menjadi sarana untuk membawa peserta didik memahami budayanya sendiri. Sejarah adalah media yang tepat untuk membawa anak pada pengalaman nyata mengenai budaya mereka. Sejarah dapat memberikan pengalaman kehidupan secara mendalam pada anak dan menjadi media 
untuk membuatnya memahami lingkungan, menemukan peluang-peluang baru dari lingkungannya.

Mengembangkan materi Sejarah yang dekat dengan peserta didik dan konstekstual dengan kehidupan mereka adalah merupakan pendekatan yang baik untuk mengembangkan kreativitas. Kreativitas dalam konteks entrepreneurship nampak pada upaya menemukan peluang-peluang inovasi dalam kegiatan ekonomi masyarakat yang dicatat sebagai fakta-fakta sejarah masa lampau. Fakta-fakta tersebut dapat ditarik pada persoalan kontemporer peserta didik. Fakta sejarah mengenai kisah sukses masyarakat lokal dan masyarakat lainnya di berbagai daerah pada bidang perdagangan bisa menjadi materi yang menarik. Misalnya, kisah sukses tukang kredit di Tasikmalaya dan para perantau masyarakat Minangkabau dan Bugis-Makasar bisa menginspirasi. Di era RI 4.0, kisah para pendiri Unicorn yang bergerak dalam industri dan perdagangan digital layak menjadi materi kontemporer. Peserta didik dekat dengan mereka melalui berbagai barang konsumsi yang dibeli oleh mereka atau orang tua mereka dengan cara digital. Demikian pula kisah sukses generasi seperti nampak pada biografi Si Anak Singkong, atau kisah sukses pengusaha agraria yang menembus pasar modern pangan di nusantara menjadi materi pelajaran yang menarik. Menghaddirkan pelaku sejarah seperti itu ke dalam kelas merupakan bagian dari metode first person historacl presentation yang dikembangkan oleh Morris (2019).

Mendekatkan peserta didik dengan peristiwa sejarah termasuk peristiwa terkait dengan lahirnya creativprerneurship bisa dilakukan dengan dua cara. Pertama, menghadirkan pelaku sejarah ke dalam kelas. Setiap orang bisa menjadi pelaku sejarah pada zamannya. Orang tua peserta didik di pedesaan yang bergerak dalam bidang pertanian bisa menjadi narasumber untuk berceritera mengenai suka dan duka sebagai petani. Kisah mereka bisa dihubungkan dengan peristiwa sejarah yang lebih besar seperti kejayaan era perdagangan dan pelayaran nusantara. Apa yang mereka lakukan kini juga dilakukan oleh pendahulu mereka. Daerah peserta didik di pedesaan atau kawasan pantai atau perkotaan menggambarkan kondisi geografis Indonesia yang strategis dan menyimpan beragam kisah sukses warganya pada masa lalu termasuk pada masa kerajaan-kerajaan Nusantara. Pengalaman orangtua mereka dapat dihubungkan melalui komodisi dagang hasil pertanian, khususnya beras dengan berkembangnya perdagangan dunia, pelayaran samudra ke berbagai Kawasan seperti Australia, India, Timur Tengah, Asia Timur, Madagaskar 
di pantai timur Afrika. Ternyata orang tua mereka kini merupakan warisan sejarah lama yang memiliki tradisi pertanian dan pelayaran yang dikembangkan secara kreatif.

Kedua, mengajak peserta didik berwisata sejarah ke lokasi yang dekat dengan mereka. Pesawahan, perkebunan, perikanan, peternakan di daerah mereka merupakan objek sejarah yang menarik. Demikian juga berbagai jenis tanaman di daerah mereka adalah yang juga sejak dulu ditanam di daerah mereka, termasuk sejak zaman Tanam Paksa atau sebelumnya. Sekolah di pedesaan atau di daerah agraris merupakan tempat yang paling menarik untuk mengajak peserta didik berimajinasi mengenai masa lalu. Mereka diajak berimajinasi dan mengambil inspirasi dalam mengembangkan creativpreneurship mengenai bagaimana mencintai daerah agraris mereka dengan mengenal segala sumber daya alam yang teredia. Rempah-rempah yang menjadi komoditas historis juga bisa ditemukan di daerah mereka. Dari sana peserta didik diajak berimajinasi ke era berkembangnya imperialisme dan kolonialisme Belanda khususnya zaman Tanam Paksa. Berbagai komoditas di daerah mereka tidak berbeda dengan komoditas yang sejak zaman dulu diperdagangkan.

Apabila kisah orangtua mereka sebagai petani tidak berbeda dengan kisah petani era kolonial maka pertanyaan historis dapat guru lakukan. Misalnya dengan mengajukan pertanyaan “apa yang dapat kita lakukan agar komoditas yang ada di daerah kita menjadi sarana untuk membuat kita sejahtera? Tindakan atau cara kreatif apa yang dapat kita lakukan agar kekayaan kita bisa dimanfaatkan untuk kemakmuran bangsa ini? Kejayaan masa lalu bangsa Indonesia, serta kepahitan bangsa dalam masa imperialism dan kolonialisme sebagai fakta Sejarah harus menjadi bahan pelajaran Sejarah. Peserta didik difasilitasi untuk mengambil pelajaran dalam menangkap peluang yang ada dan tidak mengulangi kesalahan masa lalu bangsa. Belajar dari masa lalu untuk menemukan peluang-peluang baru yang membuat lingkungan lebih bermakna adalah penting dalam pembelajaran Sejarah. Era RI 4.0 merupakan peluang yang bisa dimanfaatkan guru Sejarah yang kreatif yang bisa mendekatkan peristiwa sejarah dengan dunia nyata peserta didik pada masa kini.

Terlepas dari dampaknya bagi penderitaan bangsa Indonesia, sistem Tanam Paksa (18301870) yang dilaksanakan pemerintah kolonial Belanda merupakan tindakan kreatif. Disebut kreatif karena mereka bisa mengembangkan cara baru dalam pengelolaan sistem kolonial. Tanah subur Indonesia, khususnya Jawa dimanfaatkan dengan baik untuk perkebunan. Berbagai tanaman lokal dibudidayakan. Demikian juga tanaman dari berbagai kawasan dunia didatangkan 
ke Indonesia. Hasilnya mereka bisa mendapatkan keuntungan yang sangat besar untuk kemakmuran Negeri Belanda. Mereka memanfaatkan banyak daerah di Indonesia Cirebon, Demak, Bogor-Bandung, Garut dan Jakarta. Daerah-daerah subur tersebut dijadikan pusat kegiatan Tanam Paksa dan menghasilkan komoditas pertanian pangan yang menguntungkan. Guru Sejarah kretif bisa menggunakan tindakan kolonial “kreatif” tersebut untuk menginspirasi peserta didik. Tanah yang subur bila dikelola dengan baik akan menguntungkan. Guru-guru Sejarah di Garut, Jawa Barat, misalnya, bisa mengajukan pertanyaan. Mengapa pada saat pemerintah kolonial Belanda Kawasan Garut bisa menjadi penyumbang komoditas ekspor yang besar, akan tetapi pada masa kini pertanian kawasan subur tersebut seperti tidak bergerak? Seharusnya, topografi Garut yang merupakan daerah pegunungan dengan suhu udara yang baik bisa menghasilkan komoditas pertanian yang lebih banyak. Guru Sejarah tidak hanya mengajak peserta didik bernostalgia dengan masa lalu Garut melainkan juga memprovokasi peserta didik dengan pertanyaan kritis dan kreatif. Misalnya, apakah kini masih bisa digunakan oleh orang Garut ungkapan: "buat apa sekolah tinggi, ke kebun saja dengan bapak, kamu tidak akan melarat?" Potensi lingkungan daerah Garut yang demikian besar seharusnya bisa dimanfaatkan guru Sejarah menginspirasi secara kreatif peserta didik dalam mengembangkan keterampilanketerampilan yang relevan dengan potensi lingkungan mereka. Ungkapan di atas tentu adalah ungkapan historis yang relevansinya kini harus dilihat ulang sesuai dengan tantangan zaman.

\section{Belajar Mengenai Potensi Creativpreneurship Peserta Didik.}

Setelah merangcang RPP dengan cara berbeda dan kami sepakati bersama, proses penggalian creativpreneurship mulai dikembangkan. Kami - guru pamong dan saya - berperan sebagai observer. Mahasiswa dengan penuh percaya diri bersemangat untuk menggali kompetensi tersebut melalui pembelajaran yang sudah dirancangnya. RPP yang sudah dibuat untuk delapan pertemuan dijadikan sebagai desain pembelajan. Dalam pelaksanaannya tidak selalu sesuai dengan apa yang direncanakan. Materi pelajaran mengenai Sejarah masuk dan bekembangnya Islam di Indonesia mejadi materi utama. Ternyata materi tersebut hanya merupakan titik berangkat mahasiswa PPL tersebut untuk masuk ke materi yang dia anggap esensial: creativepreneurship. Materi tersebut dianggap telah dikuasai peserta didik setelah mereka ditugaskan mempelajarinya di rumah. Sedangkan dalam tatap muka dia memperkayanya dengan kemampuan berceritera mengenai berbagai kisah sukses tokoh masa lalu dalam 
mengembangkan kreatifitas khususnya dalam bidang ekonomi dan perdagagan. Berbagai kisah penemuan kreatif era RI 1.0, lahirnya para pedagang Islam di berbagai daerah, munculnya pengusaha lokal dalam berbagai lintas zaman dibahasnya. Hal yang sama, kisah sukses Chairul Tanjung dalam biografi Si Anak Singkong dijadikan sumber pengayaan.

Kegiatan lainnya yang kreatif adalah dia berhasil mendatangkan seorang pengusaha lokal dalam bidang agro ke dalam kelas. Dia diminta mengisahkan kesuksesaannya sebagai warga setempat yang bisa memanfaatkan peluang sehingga bisa menjadikan komoditas sayur-sayuran setempat menjadi komoditas ekspor di era RI 4.0 ini. Tokoh lokal yang sukses secara kreatif tersebut dimanfaatkan untuk menginspirasi peserta didik. Rupanya buku Moris (2009) dia baca serius sehingga first person historical presentation menjadi sumber untuk membawa siswa mengembangkan inspirasinya untuk tetap mencintai daerah agrarisnya. Pengusaha lokal dia manfaatkan secara kreatif untuk menceriterakan bagaimana naraumber tersebut merintis usaha hingga berhasil.

Pada pertemuan lainnya dia mengangkat isu kontemporer mengenai peningkatan produktifitas pertanian. Rupanya dia merujuk pada kisah sukses Revolusi Hijau Orde Baru. Melalui revolusi tersebut produksi pangan meningkat dengan tajam dan Indonesia berhasil swasembada pangan. Lalu dia jelaskan bahwa hal itu bukan ciri kreatifitas. Itu merupakan cara instan untuk meningkatkan produksi pertanian yang sebenarnya tidak ramah lingkungan. Sustainability pun terancam. Dia merujuk pada hasil penelitian Maulidah (2018) dengan mengambil contoh apa yang dilakukan oleh petani di Ciamis, Tasikmalaya dan Garut. Pertanyaan dari Maulidah dia ulang: "Akankah ada keberlanjutan atau sustainability dari sektor pertanian masyarakat pada 20 tahun ke depan apabila berbagai zat kimiawi malah mengancam kesuburan tanah dan kesehatan konsumen?”. Dia juga menjelaskan lanjut: “jika kebiasaan menggunakan bahan kimiawi pada lahan pertanian tidak saya jelaskan pada kalian maka kalian sendiri malah akan menjadi korban dari penggunaan zat-zat tersebut”. Dia menyadari betul bahwa jika pembelajaran Sejarah tidak mengembangkan pemahaman mengenai cara-cara tidak ramah lingkungan dan kecakapan khusus dalam memanfaatkan potensi daerahnya maka pembelajaran Sejarah tidak akan bermakna. Kisah sukses pengusaha lokal mengembangkan creativpreneurship dalam sektor agraris di daerah tersebut dalam mengelola pertanian organik menjadi salah satu penguatan unsur pedagogi kreatif dalam pembelajaran tersebut. 
Pemanfaatan gambar dan video juga merupakan cara kreatif dalam menginspirasi peserta didik. Merujuk pada penelitian Maulidah (2018) mahasiswa PPl tersebut membawa gambar yang menginspirasi dari cara petani Jepang menghasilkan bentuk buah-buahan yang berbeda dengan bentuk buah pada umumnya. Kreativitas petani Jepang dan teknologi pertanian mereka dalam menghasilkan bentuk dan ukuran buah-buahan dan sayuran yang berbeda sangat menginspirasi peserta didik. Melon dan semangka berbentuk kotak, mentimun dengan bentuk love dan bintang membuat kagum peserta didik. Mengemas sayuran dengan gagasan artistik dan unik sangat menarik bagi pembeli. Dia juga menampilkan video petani lokal di daerahnya mengenai bagaimana memasarkan hasil pertanian. Membuat pembeli bisa memetik langsung dari pohonnya merupakan cara yang berbeda dan menarik pembeli. Ternyata cara itu dipraktikkan oleh pengusaha lokal di daerah tersebut. Peserta didik diajak mengunjungi cara pertanian kreatif. Open learning environment sebagaimana juga dipraktikkan oleh Salmi, H., Arja K., Liisa S., (2016) dikembangkan di lokasi dia mengembangkan kegiatan PPL. Hasilnya, peserta didik mendapat banyak inspirasi. Ini yang dimaksud dengan pembelajaran Sejarah yang kreatif dan menginspirasi dan mengembangkan imajinasi peserta didik, meminjam istilah Piirto (2010). Materi Sejarah tentang masa lalu hanya sebagai salah satu sumber untuk menginnspirasi mengenai tindakan kreatif apa yang sebaiknya dilakukan pada masa kini.

Berdasarkan orservasi kami, diperoleh beberapa hasil pembelajaran. Pertama, peserta didik sangat antusias mengikuti pembelajaran Sejarah yang disajikan menjadi berbeda dari biasanya. Mereka sangat senang dengan ungkapan mahasiswa PPL bahwa ulangan sudah berlangsung saat peserta didik mengikuti pelajaran. Ulangan juga sudah dilaksanakan saat mereka menonton video, mendengar ceramah guru dan mengikuti narasumber menjelaskan mengenai bagaimana cara merintis usaha kreatif di daerah mereka. Di kebun pun mahasiswa PPL melaksanakan "ulangan" dengan mengobservasi kegiatan peserta didik. Aktifitas mereka direkam dan diberi nilai. Kedua, aspek penting dari penggalian kreatifitas dilakukan dengan semua kegiatan yang ditunjukkan di dalam dan luar kelas. Di dalam kelas, guru memberikan sejumlah pertanyaan seperti antara lain "apakah kalian ingin menjadi petani seperti Kaka (pengusaha yang diundang) yang baru saja menjelaskan pengalamannya menjadi pengusaha kreatif di daerah kita?” Serentak mereka menjawab, ingin. Ketika mahasiswa meminta angkat tangan dan ditanya siapa yang ingin menjadi petani, saya mencatatnya sebagian besar mengangkat tangan. Jawaban spontan ini tentu tidak bisa dijadikan satu-satunya ukuran 
keberhasilan. Akan tetapi, jawaban tersebut sangat menarik bila dibandingkan dengan pertanyaan sebelumnya yang sama dan tidak ada seorang pun yang ingin menjadi petani. Dari asesmen dalam kelas dengan pertanyaan tertulis juga diperoleh jawaban menarik. Pada umumnya mereka menjelaskan bahwa mereka ingin mengolah daerah pertanian mereka dengan cara berbeda seperti yang dipraktikkan oleh nara sumber tersebut. Jawaban tersebut sangat mengggembirakan. Tentu saja untuk menjadi pengusaha kreatif dengan jiwa creativpreneurship bukan pekerjaan seperti membalikan telapak tangan. Masih diperlukan pembuktian mereka kelak, paling tidak setelah lulus dari SMA ini.

Ketiga, potensi kreatif nampak setelah mereka diajak ke kebun milik pengusaha lokal tersebut. Melalui kegiatan observasi bagaimana tanaman sayuran ditanam dengan cara berbeda dari cara orangtua mereka menanam sayururan sangat menginspirasi peserta didik. Melalui tugas mendeskripsikan apa yang didengar dari penjelasan guru Sejarah (mahasiswa PPL), dilihat dari video dan gambar, dibaca dari biografi Si Anak Singkong, dirasakan di kebun milik pengusaha lokal tertsebut, dan dari kegiatan-kegaitan kreatif tersebut peserta didik menunjukkan potensi creativpreneurship-nya. Sebagian besar menjawab, mereka ingin meniru, menjadi pengusaha pertanian dan mempelajari lanjut dari pengalaman-pengalaman Sejarah masa lalu termasuk dari tokoh-tokoh yang diceriterakan dan ditampilkan di dalam dan luar kelas. Satu hal yang tidak mereka inginkan adalah menjadi petani seperti sebagian orang tua mereka: buruh tani.

\section{DAFTAR PUSTAKA}

Avishag, R. \& Sam, W. (2008). Teaching the Skill of Contextualizing in History. The Social Studies, 99(5), hlm. 202-207, DOI: 10.3200/TSSS.99.5.202-207.

Barry K. B. (2008). How to Teach Thinking Skills in Social Studies and History. The Social Studies, 99(5), hlm. 196-201, DOI: 10.3200/TSSS.99.5.196-201.

Bilton. (2010). Outdoor Learning in the Early Years. Management and Innovation (3rd Edition). New York: Routledge.

Brewer, Jo Ann \& Miller, Patricia H. (2007). Introduction to Early Childhood Education. Boston: Allyn and Bacon.

Buckler (1988) A History of World Societies, $2^{\text {nd }}$ Ed. Boston: Houghton Mifflin Company.

Caves, R. E. (2000). Creative Industries: Contracts Between Art and Commerce. Harvard University Press, Cambridge, MA. 
Cave, R. E. (2003). Contracts Between Art and Commerce. Journal of Economic Perspectives, Vol. 17 No.2, pp. 73-83.

Dayan, M. \& Di Benedetto, C.A. (2009). Antecedents and Consequences of Teamwork Quality in New Product Development Projects an Empirical Investigation. European Journal of Innovation Management, 12(1), pp.129- 155.

Fillis, I. (2010). The Role of Creativity in Entrepreneurship. Journal of Enterprising Culture, Vol. 18, No. 1, 49-81 DOI: 10.1142/S0218495810000501.

Fillis \& Rentschler. (2011). The Role of Creativity in Entrepreneurship. Lambing. Charles. 2007. Entreprenership. Pearson, Prentice Hall.

Harris and de Bruin (2017) 'Fostering Creative Pedagogies in Australian Schools', dalam Australian Journal of Teacher Education, Vol 12. Issue 9.

Kačerauskas, T. (2015). Technologies in creative economy and creative society. Journal Technological and Economic Development of Economy, 21:6, 855-868, DOI: 10.3846/20294913.2015.1036325.

Kartodirdjo, S (1995) Sejarah Indoneia Baru. Jakarta: Gramedia

Kolnhofer-Derecskei. (2016). Many Shades of Creativity. Journal Forum Scientiae Oeconomia, Vol 4 No 4, pp. 5-25.

Kuratko, D. F., \& Hodgetts, R. Morris. (1995). Entrepreneurship: A Contemporary Approach $(3 r d$ ed). New York: Dryden.

Kuratko D.E, Hornsby J.S, \& Zahra S.A. (2002). Middle manager's Perception of the Internal Environment for Corporate Entrepreneurship: Assesing a measurement scale. Journal of Business Venturing, 17(3), 253-273.

Lumpkin, G.T,\& G.G. Dess (1996). Clarifying the Entrepreneurial Orientationconstruct and Linking It to Performance. Academy of Management Review, 21(1): 135-72.

Lumpkin, G.T., Gregory G. Dess, \& Marilyn L. Taylor. (2004). Strategic Management, Text and Cases. Singapore: Mc Graw Hill Book Co.

Maulidah, N. (2018). Pengembangan Keterampilan Sosial pada Pembelajaran IPS berbasis abad 21 Melalui Pemanfaatan Sejarah Lokal Siswa. Bandung: Tesis Program Studi Pendidikan Dasar Sekolah Pascasarjana Universitas Pendidikan Indonesia.

McKeever, E., Sarah J. \& Alistair A. (2014). Embedded entrepreneurship in the creative reconstruction of place. Journal of Business Venturing, 3(33). 
Morris, R. V. (2009). Bringings History To Life: First Peson Historical Presentation in Elementary and Middle Classrooms. New York: Rowman and Littlefield Education.

Ornstein, L. \& Gutek. 2011. Foundation of Education. Chicago: Wadsworth Cengage Learning. Oscarius (2016) Entrepreneur: Bagaimana Menciptakannya, Wawasan dan Ide dalam Proses Pengajaran Kewirausahaan. Jakarta: Gramedia.

Romer, D. (2006). Advanced Macroeconomics, 3rd edition. New York: Mc.Graw-Hill.

Runco and Jaeger (2012) the Standard Definition of Creativity, in Creativity Research Journal, 24 (1) 92-96.

Salmi, H., Arja K., Liisa S., (2016). Teacher Profesional Development in Outdoor and Open Learning Environment: A Research Based Model. Journal Creative Education, Vol. 7 No. 10, 8 Juli 2018.

Sadler-Smith, E. (2016). Wallas' four-stage model of the creative process: More than meets the eye?. Creativity Research Journal, 27 (4).

Schmidt, et al (2013). The economic value of goal setting to employers. Journal New developments in goal setting and task performance, pp. 40-44.

Schumpeter J. (1934): The Theory of Economic Development. An Inquiry into Profits, Capital, Credit, Interest and the Business Cycle. Harvard University.

Schumpeter J. (1947). The Creative Response in Economic History. The Journal of Economic History, Vol. 7 No. 2.

Selkrig, M and Keamy, Kim (2017) 'Creative pedagogy: A Case for teacher' creative learning being at the centre, dalam Teching Education, 2017, Melbourne: Tailor \& Francis.

Supriatna, N (2018) Prosa dari Praha, Narasi Historis masayurakt Konsumen era kapitalisme Global. Bandung: Rosda.

Supriatna, N (2007) Konstruksi Pembelajaran Sejarah Kritis, Bandung: Histoia Utama Press. 